\title{
Biazrovia, a new genus of lichenicolous ascomycetes from Asia
}

\section{Mikhail P. Zhurbenko ${ }^{1 *} \&$ Javier Etayo ${ }^{2}$}

\author{
${ }^{1}$ Laboratory of the Systematics and Geography of Fungi, Komarov Botanical Institute, Russian Academy \\ of Sciences, Professor Popov 2, St.-Petersburg, 197376, Russia \\ ${ }^{2}$ Navarro Villoslada, 16-3 dcha., E-31003 Pamplona, Spain
}

Received 27 November 2012 / Accepted 21 December 2012 / Published 11 January 2013

Zhurbenko, M.P. \& Etayo, J. 2013. Biazrovia, a new genus of lichenicolous ascomycetes from Asia. Mycobiota 1: 51-56. doi: 10.12664/mycobiota.2013.01.05

\begin{abstract}
The genus Biazrovia is described from Siberia for the single new species $B$. stereocaulicola growing on Stereocaulon species. It is characterized by a lichenicolous habit; finally urceolate orange-brown apothecia; a cupulate non-hairy exciple; a hyaline, I-, K/I- hymenium; filiform, apically swollen paraphyses; 8-spored, I-, K/ I- asci with an apically thickened wall without a distinct ocular chamber; and hyaline, trans-septate, smooth-walled, non-halonate ascospores. The new genus is provisionally included in the Ostropales.
\end{abstract}

Key words: lichen-inhabiting fungi, Ostropales, Russia, Stereocaulon

\section{Introduction}

In a recent treatment of lichenicolous fungi growing on species of Stereocaulon in the Holarctic, a "pyrenomycete 2" found in Siberia was mentioned (Zhurbenko 2010). Further studies of relevant material suggested that it represents an undescribed species of a previously unknown genus of discomycetes, which is formally described below as Biazrovia. The diversity of lichenicolous fungi known to grow on Stereocaulon thus is enlarged to 32 species representing 26 genera (Etayo 2002, 2010; Berger \& Priemetzhofer 2008; Zhurbenko 2010; Kukwa et al. 2012; Zhurbenko \& Braun 2012), two of the latter (Cecidiomyces U. Braun \& Zhurb. and the newly described Biazrovia) being exclusively known from this host genus.

\footnotetext{
${ }^{*}$ Corresponding author: e-mail: zhurb58@gmail.com
} 


\section{Materials and methods}

The material was examined and photographed using Zeiss microscopes Stemi 2000-CS and Axio Imager A1 equipped with Nomarski differential interference contrast optics. Microscopic examination was carried out on material mounted in water, $10 \% \mathrm{KOH}(\mathrm{K})$, or Lugol's iodine, directly (I) or after a $\mathrm{KOH}$ pre-treatment (K/I). Measurements were taken from water mounts. Dimensions of ascospores were rounded to the nearest $0.5 \mu \mathrm{m}$. Their length, breadth and length/breadth ratio (l/b) are given as: (min-) $\{\mathrm{X}-\mathrm{SD}\}-\{\mathrm{X}+$ $\mathrm{SD}\}(-\max )$, where min and max are the extreme values, $\mathrm{X}$ the arithmetic mean, and SD the corresponding standard deviation. The Ascomycota classification follows Lumbsch \& Huhndorf (2007), except for the placement of Spirographa Zahlbr. in Ostropales (Diederich 2004). The material examined is housed in the herbarium of the V.L. Komarov Botanical Institute in St. Petersburg, Russia (LE).

\section{Taxonomy}

Biazrovia Zhurb. \& Etayo, gen. nov.

MycoBank MB 802980

Lichenicolous ascomycetes. Ascomata apothecia, semi-immersed to sessile, initially subglobose and almost closed, later deeply urceolate, with circular non-dentate opening, fleshy, shades of orange-brown. Exciple cupulate, without hairs, shades of yellowish brown, in surface view resembling textura angularis or textura intricata, K-. Periphysoids absent. Epihymenium and subhymenium hyaline, indistinct. Hymenium hyaline, all parts I-, K/ I-. Paraphyses filiform, scarcely septate, occasionally branched, with markedly swollen apices. Asci subcylindrical, wall apically thickened, without distinct ocular chamber when mature, I-, K/I-, 8-spored. Ascospores hyaline, narrowly ellipsoid, trans-septate, smoothwalled, non-halonate, guttulate, overlapping uni- or biseriate in the ascus. Conidiomata not observed.

Etymology. Dedicated to the outstanding Russian lichenologist Lev Biazrov, who made significant contribution to the knowledge of the lichen flora of Central Asia.

Type species: Biazrovia stereocaulicola Zhurb. \& Etayo

Biazrovia stereocaulicola Zhurb. \& Etayo, sp. nov.

Fig. 1

MycoBank MB 80298I

Similar to Paschelkiella pini (Romell) Sherwood, but differs in the ecology, capitate paraphyses, I- asci, and narrowly ellipsoid, 3-septate ascospores.

Type: RUSSIA: Siberia, Irkutsk Region, 2 km SE of Anchuk, Bol'shaya Bystraya River, $51^{\circ} 44^{\prime} \mathrm{N}, 103^{\circ} 29^{\prime} \mathrm{E}$, alt. $700 \mathrm{~m}$, taiga forest, pebble among shrubs by the river bank, on Stereocaulon glareosum (mostly stems, occasionally phyllocladia), 9 Jun 2005, M. Zhurbenko 0554 (LE 233719 - holotype).

Ascomata apothecia, macroscopically reminiscent of Taxus baccata fruits, semiimmersed to sessile, $100-250 \mu \mathrm{m}$ diam, initially subglobose, almost closed, and resembling perithecia, later deeply urceolate, with wide, circular, non-dentate opening up to $125 \mu \mathrm{m}$ diam., glabrous, fleshy, vinaceous, cinnamon or orange-brown. Exciple cupulate, 20-35 

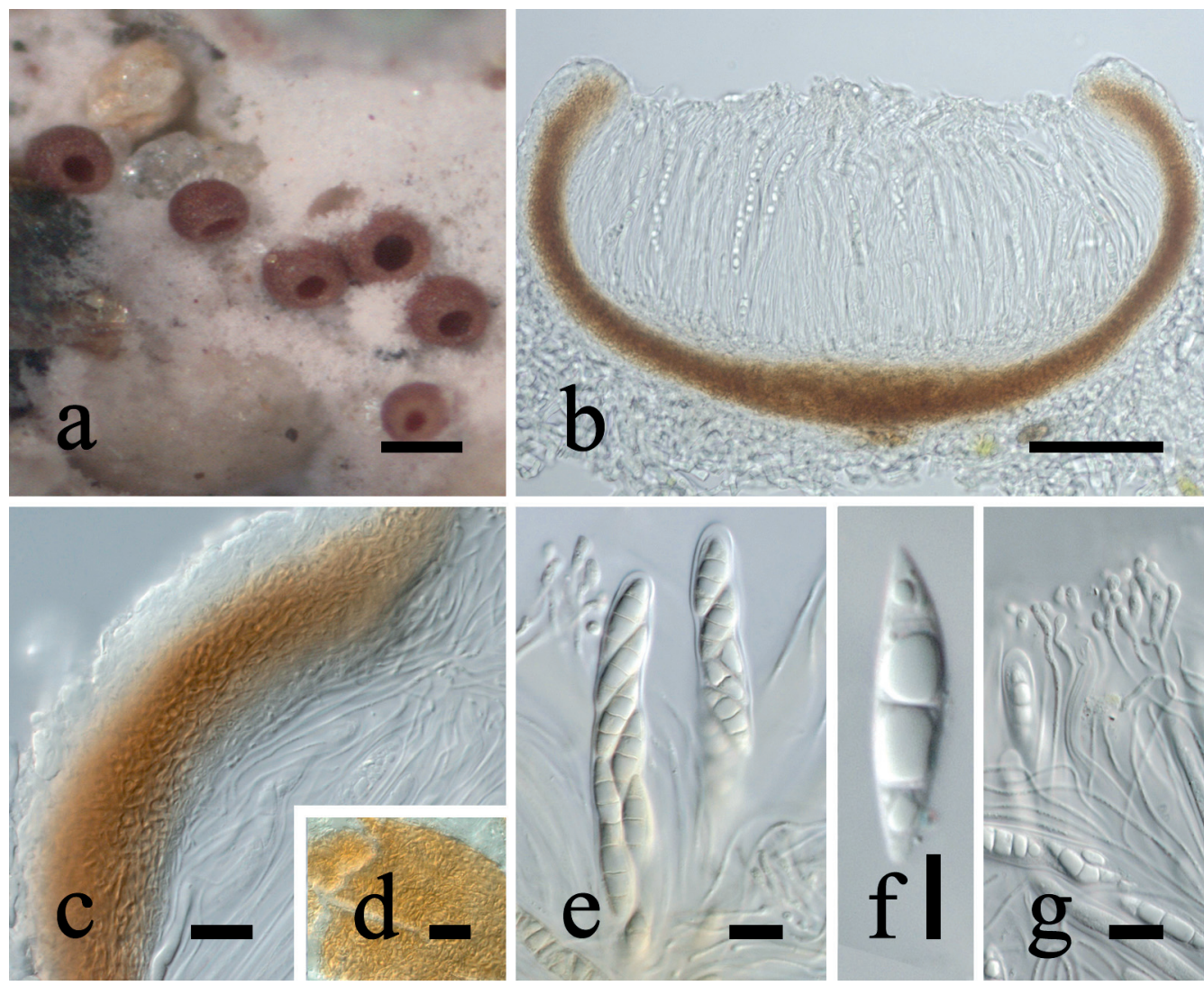

Fig. 1. Biazrovia stereocaulicola (holotype): $\mathbf{a}$ - ascomata habitus; $\mathbf{b}$ - ascoma in cross section (in water); $\mathbf{c}$ - wall of ascoma in cross section (in water); $\mathbf{d}$ - squashed wall of ascoma in surface view (in water); $\mathbf{e}$ - asci with spores (in I); $\mathbf{f}$ - ascospore (in $\mathrm{K}$ ); $\mathbf{g}$ - paraphyses (in water). Bars: $\mathrm{a}=200 \mu \mathrm{m} ; \mathrm{b}=50 \mu \mathrm{m} ; \mathrm{c}, \mathrm{e}, \mathrm{g}=10 \mu \mathrm{m} ; \mathrm{d}, \mathrm{f}=5 \mu \mathrm{m}$

$\mu \mathrm{m}$ thick, without hairs, yellowish brown to cinnamon throughout except outer hyaline layer 5-10 $\mu \mathrm{m}$ thick in exposed parts, in cross section of angular-elongated cells, in surface view resembling textura angularis or textura intricata, of cells 3-7 $\mu \mathrm{m}$ across, K-. Periphysoids absent. Epihymenium hyaline, indistinct. Hymenium hyaline, ca. $100 \mu \mathrm{m}$ tall, I-, K/I-. Subhymenium hyaline, ca. $10 \mu \mathrm{m}$ tall. Paraphyses numerous, persistent, filiform, scarcely septate, occasionally branched above into two unequal arms, ca. $1 \mu \mathrm{m}$ diam., with non-pigmented, markedly swollen, sometimes slightly strangulated apices 2.5-4 $\mu \mathrm{m}$ diam. Asci subcylindrical, lateral wall ca. $1 \mu \mathrm{m}$ thick, apical dome 3-10 $\mu \mathrm{m}$ tall, distinct ocular chamber absent, but in young asci occurs small apical indentation, 75-91(-100) $\times(7-) 8-10(-12) \mu \mathrm{m}(\mathrm{n}=17), 8$-spored, easily separating in $\mathrm{K}, \mathrm{I}-, \mathrm{K} / \mathrm{I}-$. Ascospores hyaline, ellipsoid, symmetric or occasionally slightly attenuated below, with subacute apices, 3-septate when mature, not constricted at the septa, (12-)15-20(-28) × 
(4-)4.5-5.5(-6.5) $\mu \mathrm{m}, \mathrm{l} / \mathrm{b}=(2.4-) 2.9-3.9(-4.7)(\mathrm{n}=114)$, smooth-walled, non-halonate, guttulate, overlapping uni- or biseriate in the ascus. Conidiomata not observed.

Distribution and hosts. Found in two localities in northern and southern Siberia within arctic tundra and southern taiga forest biomes. The species grows on healthy-looking tomentose stems or occasionally on phyllocladia of Stereocaulon glareosum and S. rivulorum. Pathogenicity not observed.

Additional specimen examined: RUSSIA: Siberia, Taimyr Pen., Dikson Island, $73^{\circ} 30^{\prime}$ N, $80^{\circ} 20^{\prime}$ E, alt. 30 m, stony tundra, on Stereocaulon rivulorum (stems), 7 Jul 1990, M. Zhurbenko 90903a (LE 233 719a).

\section{Discussion}

With respect to genera containing lichenicolous species, Biazrovia is comparable to the ostropalean genera Odontotrema Nyl., Paralethariicola Calat., Etayo \& Diederich, and Spirographa, and the helotialean genera Llimoniella Hafellner \& Nav.-Ros., Rhymbocarpus Zopf, Skyttea Sherwood, D. Hawksw. \& Coppins, and Unguiculariopsis Rehm (SherwoodPike 1987; Zhuang 1988; Holien \& Triebel 1996; Diederich \& Etayo 2000; Calatayud et al. 2001; Diederich et al. 2002, 2010; Diederich 2004; Flakus \& Kukwa 2012). The genus Odontotrema differs from Biazrovia by its often radially fissured ascomata of cleistohymenial nature, usually present well-developed periphysoids, a I+ finally red hymenium, and asci with a distinct ocular chamber. Paralethariicola shares the above mentioned features with Odontotrema and additionally differs from the new genus by the presence of excipular hairs and curved ascospores. Spirographa is distinguished from Biazrovia by its black or dark brown ascomata of cleistohymenial nature, a dark yellow granulose layer covering the hymenium, polyspored asci with an apically only slightly thickened wall, and acicular, usually curved ascospores. It is noteworthy that many species currently placed in Odontotremataceae have periphysoids, which are absent in Biazrovia, but according to Diederich (2004) this character is non-diagnostic for the family. The genus Llimoniella is distinguished from Biazrovia by its dark brown to blackish, non-urceolate apothecia, apically indistinctly swollen paraphyses, and usually hardly thickened apical ascal wall. Rhymbocarpus differs from the new genus in its black ascomata, the presence of excipular hairs in some species, a greenish, $\mathrm{K}+$ olivaceous epihymenium, apically slightly swollen paraphyses, and apically not or slightly thickened ascal wall. Skyttea has dark-coloured ascomata, permanent excipular hairs, apically not or poorly swollen paraphyses, and asci with a small, but distinct ocular chamber. Most species of Unguiculariopsis are characterized by an exciple covered by hook-shaped hairs with a swollen base. However, some lichenicolous species of the genus do not have such hairs, and some of them, for instance $U$. acrocordiae (Diederich) Diederich \& Etayo (Diederich \& Etayo 2000), have apically thickened asci similar to those observed in Biazrovia stereocaulicola. Amongst the non-lichenicolous genera, Biazrovia stereocaulicola seems to be most similar morphologically to the monotypic genus Paschelkiella Sherwood currently placed in Odontotremataceae (Sherwood-Pike 1987). Paschelkiella pini is a saprotroph on decorticated wood and differs from the new species in its ecology, inclusion of host tissue in the exciple, diffusely I+ blue asci, non-capitate paraphyses, and cylindrical 1-septate 
ascospores. It is notable that ascomata of Paschelkiella are not typical for Odontotremataceae, where they are mostly black, with at least partly carbonized exciple and radially striate/ dentate opening. Until the new species is subjected to molecular phylogenetic analysis we suggest that it should be placed in the Ostropales.

Acknowledgements. Paul Diederich and Larisa N. Vasil'eva are thanked for valuable comments on the manuscript. A. Elizabeth Arnold is thanked for editorial assistance with English.

\section{References}

Berger, F. \& Priemetzhofer, F. 2008. Neufunde und interessante Nachweise von Flechten und flechtenbewohnenden Pilzen von den Azoren. - Herzogia 21: 125-146.

Calatayud, V., Etayo, J. \& Diederich, P. 2001. Paralethariicola aspiciliae (Ostropales, Odontotremataceae), a new genus and species of lichenicolous fungi. - The Lichenologist 33: 477-482. doi: 10.1006/ lich.2001.0360

Diederich, P. 2004. Spirographa. - In: T.H. Nash III, B.D. Ryan, P. Diederich, C. Gries \& F. Bungartz (eds). Lichen flora of the Greater Sonoran Desert Region. Vol. 2. Pp. 702-703. Lichens Unlimited, Arizona State University, Tempe, Arizona.

Diederich, P. \& Etayo, J. 2000. A synopsis of the genera Skyttea, Llimoniella and Rhymbocarpus (lichenicolous Ascomycota, Leotiales). - The Lichenologist 32: 423-485. doi: 10.1006/lich.2000.0290

Diederich, P., Zhurbenko, M. \& Etayo, J. 2002. The lichenicolous species of Odontotrema (syn. Lethariicola) (Ascomycota, Ostropales). - The Lichenologist 34: 479-501. doi: 10.1006/lich.2002.0418

Diederich, P., Ertz, D. \& Etayo, J. 2010. An enlarged concept of Llimoniella (lichenicolous Helotiales), with a revised key to the species and notes on related genera. - The Lichenologist 42: 253-269. doi: $10.1017 /$ S0024282909990612

Etayo, J. 2002. Aportación al conocimiento de los hongos liquenícolas de Colombia. - Bibliotheca Lichenologica 84: 1-154.

Etayo, J. 2010. Hongos liquenícolas de Perú Homenaje a Rolf Santesson. - Bulletin de la Société linnéenne de Provence 61: 1-46.

Flakus, A. \& Kukwa, M. 2012. New species of lichenicolous fungi from Bolivia. - The Lichenologist 44: 469-477. doi: 10.1017/S0024282912000059

Holien, H. \& Triebel, D. 1996. Spirographa vinosa, a new odontotremoid fungus on Ochrolechia and Pertusaria. - The Lichenologist 28: 307-313. doi: 10.1006/lich.1996.0028; doi: 10.1017/ S0024282996000412

Kukwa, M., Etayo, J. \& Flakus, A. 2012. Plectocarpon stereocaulicola: a new lichenicolous fungus (Ascomycota: Roccellaceae) from Bolivia. - The Lichenologist 44: 479-482. doi: 10.1017/S0024282912000151

Lumbsch, H.T. \& Huhndorf, S.M. 2007. Outline of Ascomycota - 2007. - Myconet 13: 1-58.

Sherwood-Pike, M.A. 1987. The Ostropalean fungi III: the Odontotremataceae. - Mycotaxon 28: 137-177.

Zhuang, W.-Y. 1988. A monograph of the genus Unguiculariopsis (Leotiaceae, Encoelioideae). - Mycotaxon 32: $1-83$. 
Zhurbenko, M.P. 2010. Lichenicolous fungi and lichens growing on Stereocaulon from the Holarctic, with a key to the known species. - Opuscula Philolichenum 8: 9-39.

Zhurbenko, M.P. \& Braun, U. 2012. Cecidiomyces, a new subantarctic lichenicolous hyphomycete genus. - The Lichenologist 44: 801-806. doi: 10.1017/S0024282912000527 